\title{
Sağlıkta Şiddete Hasta Şikayetlerinde Yer Alan Olumsuz İadeler Açısından Bir Bakış: Konya Örneği*
}

\section{An Outlook to the Violence in Health System in Terms of Negative Statements of Patient Complaints: Konya Example}

\author{
Yrd. Doç. Dr. Ayhan Uludağ - Prof. Dr. Nazmi Zengin
}

\begin{abstract}
Öz
Hasta şikayetleri, sağlık çalışanı-hasta ilişkisine dair önemli ipuçları vermektedir. Sağllkta hasta ve yakınları kaynakl şiddet olgusunun üzerinde ciddiyetle durulmalıdır. Hasta şikayetleri incelendiğinde, şiddet olgusunun nedenlerine ilişkin bulgular elde edilebilecektir. Çalışmada, Konya Sağlık Müdürlüğü Hasta Hakları İl Koordinatörlüğ̈̈nün hasta hakları sistemine 2012 yllında yapılan 663 başvuruda geçen olumsuz ifadelerin kullanılma durumu incelenmiștir. Elde edilen veriler ışığında hasta algiları ve tutumlarınin belirlenmesi amaçlanmıştır. Iffadeler kodlandiktan sonra, istatistik paket programına girilerek sayısallaştırılmış ve analize tabi tutulmuştur. Şikayetlerde, 36 olumsuz ifadenin toplam 917 kez geçtiği bulunmuştur. Sonuç olarak hasta-sağlık çalışanı ilişkisinde olumsuz ifadeler, hasta algi ve tutumlarma olumsuz etki etmektedir.
\end{abstract}

Anahtar Kelimeler: Hasta Hakları, İletişim, Olumsuz Ifade, Şiddet

\footnotetext{
Abstract

Patient complaints give important clues on health care staff-patient relationship. The violence of patients and their relatives should be taken seriously. Analyzing the patient complaints, it is possible to obtain findings regarding the reasons of violence. This study examined
}

the use of negative statements in 663 applications made to the patients' rights system under the control of Konya Directorate of Health Provincial Coordination Unit of Patient Rights in 2012. It was aimed to determine the patient perceptions and attitudes in the light of the data obtained. Statements after being encoded, was entered into a statistical software package, digitized and subjected to analysis. 36 negative statements were found to take place 917 times in the complaints. As a result, the negative statements in patient - health care staff relationship have a negative impact on patient perceptions and attitudes.

Keywords: Patient Rights, Communication, Negative Statements, Violence

\section{Giriş}

Sağlık çalışanları ile birlikte anılma sıklığı son zamanlarda giderek artan şiddet kavramı, üzerinde önemle durulması gereken bir olgu haline gelmiştir. Sağlık çalışanına yönelik şiddetin varlığı artık herkesçe tartışılmaksızın kabul görmektedir. Ortada bir şiddet varsa elbette bunun bilinen veya henüz bilinmeyen bazı nedenlerinin olması doğaldır. Çalışmada, şiddetle ilgili hasta hakları sistemine yapılan hasta şikayetlerinden bazı ipuçları elde etme amacı güdülmüştür.

Yrd. Doç. Dr. Ayhan Uludağ, Necmettin Erbakan Üniversitesi Sağlık Bilimleri Fakültesi, ayhanuludag@yahoo.com

Prof. Dr. Nazmi Zengin, Necmettin Erbakan Üniversitesi Meram Tip Fakültesi, nzengin@konya.edu.tr

* 5. Uluslararası Hasta ve Çalışan Hakları Kongresi, Sağlık Akademisyenleri Derneği ve HAKSAD, Antalya, 20-23 Kasım 2013. Kongre Başkanları Prof. Dr. Seval AKGÜN Başkent Üniversitesi-Sağlık Akademisyenleri Derneği, Dr. Antonio Chiarenza Koordinatör-Dünya Sağlık Örgütü. "Hasta Şikayetlerinde Bulunan Olumsuz İfadelere Bir Bakış: Konya Örneği” başlığıyla Sözlü Bildiri olarak sunulmuştur. 
Sağlık çalışanına şiddet olgusu yeni bir kavram olmasa da, artış sıklığı veya ölüme varan eylemler yaşanması gibi nedenlerden dolayı ülke gündemine epey tartışmayı beraberinde getirmiştir. Tepkisel birçok açılama, şiddet meselesinde tartışmaların yönünü belirleyici hale gelmiştir. Bu minvalde şekillenen tartışmalar ise, istenen derinliğe ulaşmayan bir aşamada kalarak yüzeyselliğe mahkum olmuştur. Belki de sonuç almak için uzun uğraşlar gerektiğinden dolayı, konu bu şekilde gündemde tutulmaktadır. Şiddete yönelik özellikle de sağlık alanında ki şiddetin kökenine dönük ciddi çalışmalar olamazsa, çözüm noktasında ciddi bir ilerleme gösterilemeyeceği gibi mevcut kısır döngü de devam edecektir.

Sağlıkta şiddetin üzerinde durulması gereken bir konu, Bauman (1999, s.51) tarafindan dile getirilen 'biz' ve 'onlar' kavramının tartışılmasıdır. Bauman'a göre 'biz' ve 'onlar' yalnızca iki ayrı insan grubu değil, tamamen farklı iki tutum arasındaki, duygusal bağlanma ve antipati, güven ve kuşku, güvenlik ve korku, işbirliği ve çekişme arasındaki ayrımı temsil etmektedir. Bu bağlamda sağlıkta şiddetin 'biz' ve 'onlar' şeklinde değerlendirilmesi ve ona göre politikalar üretilme gayreti yapılabilecek en büyük hatadır.

İnsanlarla kurulan iletişimde, özellikle de kişilerarası iletişimde dilin nasıl kullanıldığ Dil bu süreçte iyi kullanılabildiği takdirde iletişim etkin bir şekilde gerçekleştirilebilir (Okay, 2009, s.65). İletişimi doğru yönlendirmek yükümlülüğün sağllk çalışanlarında olduğu gerçeği dikkate alındığında, hasta ve yakınlarıyla kurulan iletişimde, sağlık çalişanlarının kullandığı dilin niteliğ̆i daha da önem kazanmaktadır.

Sağlıkta şiddet, sağllk hizmetlerinin yürütülmesinde önemli bir problem olarak karşımıza çıkmaktadır. Problem kavramı ise, istenilen durumdan sapmaya neden olan, amaca ulaşmayı engelleyen durumlar şeklinde tanımlanmaktadır (Lyles ve Joiner, 1986, s.117). İnsanların sağlığını koruma ve geri kazanmasının amacının temel alındığı sağlık sistemi ise sağlıkta şiddet problemini çözmelidir. Problem çözme ise; içinde bulunulan durumla ulaşılmak istenen amaç arasındaki engeli ortadan kaldırmaya yönelik bilişsel ve davranışsal bir süreç (Öğülmüş, 2001, s.10) şeklinde tarif edilmektedir.

Sanders (1999, s.29) tarafından dile getirilen "algılama anlamaya, anlama da algılamaya biçim verir" gö- rüşünden hareket edilirse, sağlıkta şiddette yaşanan kısır döngüyü anlamlandırma çabaları doğru şekilde ele alınabilir. Yine Sanders (1999, s.30) gözün, saldırgan bir organ olarak işlev gördüğünü belirtirken, kulağın ise edilgen bir alımlama organı olarak onun tam tersi görevi üstlendiğine vurgu yapmaktadır. Kulak, gözden farklı olarak her türlü uyarıya açıtır ve tıkamak gibi özel bir çaba sarfetmeden duymaması mümkün değildir. Sağlıkta şiddet kavramında göz ve kulak duyu organlarının yaptığı alımlamaların rolü çalışmada değerlendirilmektedir.

İnsanlar, hayatının farklı dönemlerinde farklı nedenlerden kaynaklı sağlık sorunları yaşamaktadırlar. Sağlıklı olduklarının tersine, sağlık sorunu yaşadıkları dönemde daha hassas ve daha kırılgan bir hale bürünmektedir ve bu da doğaldır. İşte bu dönemde sağlık hizmeti sunanlardan kendilerine yardım isterken, bunu da iyi bir iletişim kurma çabası içerisinde olan bir sağlık çalışanı beklentisi içinde bulunmaktadır. Hekimlerin hasta ve yakınlarına anlayışlı yaklaştığ 1 ve sorunlarını gerçek bir iletişimle paylaştığ durumlarda iletişiminin etkin ve sevimli olması beklenebilmektedir (Okay, 2009, s.206). Ayrıca yazarlara göre (Gordon ve Edwards, 1997, s.4) sağlik personelinin hastalarla konuşma biçimleri, onlara davranış biçimlerinin olumlu olup olmaması, hastalara onlarla ilişkilerinden sağladıkları doyumun derecesini belirlemektedir.

Çalışmanın amacı, sağlık hizmetlerinde yaşanan sağlıkta şiddetin nedenlerine dair yeni bilgi ve bulgu elde edebilmektir. Şiddete neden olabilecek sağlık sistemi ve sağlık personelinden kaynaklı sorunları, hizmet alan halkın değerlendirmeleri ışığında analiz edilmeye çalışılacaktır. Araştırma da özellikle hasta şikayetleri kullanılmış olup, tutum ölçümünden daha çok davranışa dönüşmüş algıların varlığ 1 tespit edilmesi amaçlanmıştır.

\section{Sağlıkta Şiddet}

Hayatın her alanında bir şekilde kendine yer bulan şiddetin tarihi insanlığın başlangıcına kadar gitmektedir. Uygulayan açısından bakıldığında şiddet için birçok mazeret üretilebilmektedir. Hatta bu mazeretlerin de çoğu zaman ciddi anlamda haklı ve geçerli görülme eğilimi bilinmektedir. Şiddet, üzerinde birçok bilimsel çalışma yapılan, azaltılması için çaba gösterilen ciddi bir sorundur. 
İnsanlarla doğru bir iletişim kurmak şiddet ve saldırganlığı azaltmak için önemli bir etken olabilir. Etkili bir iletişim için, üzerinde karşılıklı anlaşılan ortak zemine yönlendiren destek ve tartışma temel faktördür. İkinci olarak, iletişim çabası içinde bulunmak 'anlaşma' anlamına gelmemektedir. Yine 'anlaşmazlık' ile 'yanlış anlama' da aynı şey değildir. Uzlaşılan ortak zemin aslında kişilerin birbirinin farklı bakış açılarını anlamak ve bu farkların gerçek ve kabul edilebilir oldukları konusunda uzlaşmasıdır. Alternatiflerden hangisinin en iyisi olduğunu tartışmaktansa, her birini ayrıntılarıyla anlamaya çalışmak tarafları daha verimli sonuca götürmektedir (Kurtz vd., 1998, s.153).

Doktorlar gibi hemşirelik mesleğinin de günümüzde hastaya daha az, bilime daha çok dayalı hale geldiği bilinmektedir. Mecburen hemşireler artık anlık teknolojik bakımla daha çok ilgili olmak durumundadır. Yoğun kırtasiye işlemleri ve karmaşı makinelerle uğraşmak zorunda kalmaları ve diğer işlerden dolayı hemşireler hastaya şefkat göstermekten uzak kalabilmektedir (Gordon ve Edwards, 1997, s.30).

Sağlık çalışanı ve hasta ilişkisinde sorun yaşamak, tarafların şiddete başvurmasını hiçbir şekilde kabul edilebilir göstermez. Bu çalışmada, istenmeyen şiddet durumunun var olup olmadığ dır, çünkü artık şiddet olgusu ciddi bir fiili duruma dönüşmüştür. Bu konuda yapılmış bazı araştırma sonuçlarını irdelemek çalışma konusunun önemini anlatmak açısından yararlı olacaktır.

Şiddet konusunda hasta ve yakınlarının neden böyle davrandıklarına dair birçok araştırma yapılmasına karşın, sağlık çalışanlarının bu konuda rolüne dair ciddi çalışmalara rastlanmamaktadır. Bu nedenle belki de şiddete karşı üretilen politikalar uzun soluklu ve sonuç alıcı nitelikte olamamaktadır. Yazarlar (Gordon ve Edwards, 1997, s.144) sağlık çalışanları tarafindan zor hastalara verilen isimlerden bir derleme yapmaktadır: "Sevimsizler, acaipler, işe yaramazlar, mızmızlar, yapışkanlar, burnu büyükler, kendini yiyip bitirenler, iğrençler”...

Sağlık iş yerinde şiddet; bir veya birden fazla sağlık çalışanı, hasta/hasta yakınları veya üçüncü şahıslar ile diğer sağlık çalışanları arasında cereyan eden ve fiziksel veya ruhsal olumsuz sonuç yaratan davranışlar şeklinde tanımlanabilir (Sadullah, 2009, s.454). Isparta-Burdur Tabip Odası'nın yaptığı çalışmaya katılan sağlık çalışanlarının \% 84' ü küfür, hakaret, tükürme, tehdit içeren şiddet olaylarına maruz kaldığını belirtmiştir. Bu şiddet olaylarının yanında sağlık çalışanları, tokat, yumruk, aletle saldırı, cinsel taciz gibi diğer şiddet içerikli olaylara da maruz kaldığını ifade etmiştir (Aydın, 2008, s.17). Bir başka araştırmada da, iş yeri şiddetine maruz kalma bakımından sağlık çalışanları ikinci sırada yer almaktadır. Sağlık kurumlarındaki şiddet, hasta, hasta yakınları veya diğer herhangi bir bireyden gelen, sağlık çalışanı açısından risk oluşturan, tehdit davranışı, fiziksel saldırı ve cinsel saldırıdan oluşmaktadır (Saines, 1999, s.9).

Dursun'un (2012, s.109) yaptığı çalışmada katılımc1ların en fazla maruz kaldığ 1 şiddet türü, \% 55.6 ile sözel şiddettir. Bunu \%26.7 ile fiziksel şiddet davranışları izlemektedir. Katılımciların en az oranda maruz kaldıkları saldırı türü ise \%6.2 ile cinsel şiddet davranışlarıdır. Veriler bir bütün olarak değerlendirildiğinde, katılımcıların \%58.5'inin herhangi bir şiddet türüne maruz kaldığı görülmektedir.

Şiddeti uygulayan açısından yapılan bir araştırma ise Gaziantep il merkezinde gerçekleştirilmiştir. Gaziantep il merkezinde Kasım 2012-Şubat 2013 tarihleri arasında 1600 sağlık çalışanı olmayan katılımcı üzerinde yapılan çalışmada, en çok şiddet uygulayan, şiddete daha meyilli olan, daha agresif düşüncelere sahip olan ve daha saldırgan davranışlar sergileyen katılımcıların en çok; 24-30 yaş grubunda, erkekler ve eğitim düzeyi düşük (üniversite mezunu olmayan) olan kişiler olduğu belirlenmiştir. Özellikle saldırganlık durumunda sopa, bıçak gibi kesici alet ve silah kullananların \%100'ü üniversite mezunu olmayan kişilerdir. Çalışmada; fiziksel şiddet uygulayanların ve şiddetin hak arama yöntemi olduğunu düşünenlerin büyük çoğunluğunun alkol alışkanlığına sahip kişilerin olduğu görülmüştür. Sağlık çalışanı ile en az bir kez tartı̧̧ma yaşayan ve fiziksel şiddet uygulayanların şiddet uyguladıklarında karşılığında alacakları cezalar hakkında bilgi sahibi olup olmaması ile bir ilişskisinin olmaması ilginçtir. Bilgi sahibi olan da olmayanda birbirlerine yakın davranışlar sergilemişlerdir (Sarcan, 2013, s.91). Yerel bir çalışmayı tamamen ülke çapına genelleştirmek elbette bilimsel bir yaklaşım olmayacaktır ama yine de bu çalışma şiddet uygulayanlar açısından ciddi bir fikir vermektedir.

Gaziantep ilinde gerçekleştirilen yukarıda ki çalışmanın bulgularına benzer sonuç elde edilen çalışma- 
da ise, Türkiye'de sağlık çalışanlarına karşı şiddetin önemli bir sorun olduğu vurgusu yapılmaktadır. Çalışmanın sonuçlarına bakıldığında, sağlık çalışanına şiddet uygulayan saldırganların özelliklerine bakıldığında; daha çok erkek ve ruhsal sorunları olan ve alkol bağımlısı, madde kullanıcısı kişilerden oluştuğu görülmektedir. Ayrıca en sık saldırı nedeninin, organizasyonel sorunlardan kaynakladığı (Özcan ve Bilgin, 2011, s.1454) ortada iken bu konunun gerektiği kadar değerlendirilmediği ortadadır.

İzmir Tabip Odası tarafından 1-15 Nisan 2012 tarihleri arasında, İzmir'de toplam bin 639 kişi üzerinde gerçekleştirilen ankette, kişilere sağlık çalışmasında sağlık hizmeti ve hekimlik ile ilgili 25 soru yöneltilmiştir. Anket sonuçlarına göre, vatandaşların \%75’i aldığı sağlık hizmetini kaliteli bulmadığını; \%71' i ise aldığı sağlık hizmetinden memnun olmadığını, \%70'i hekim-hasta iletișiminde sorun olduğunu düşündüğünü belirtmiştir (İzmir Tabip Odası, 2012). Araştırmadan elde edilen sonuçlara bakıldığında halkın önemli bir kısmının hasta-hekim iletişiminde bir sorun olduğunu belirtmesi dikkate değerdir.

Hasta şikayetleri, sağlık çalışanı hasta ilişsisinde önemli ipuçları veren veri kaynağıdır. Hasta şikayetlerinden hareketle İzmir'de yapılan uzmanlık tezinde işleyişle ilgili şikayetler 9 alt başlık altında gruplandırılmıştır. Bunların içinde ne fazla şikayet edilen konu \%26.5 ile 'personelin davranışlarındaki olumsuzluk ve ikinci olarak \%25 ile 'bekleme süresinin uzun olması' şikayet nedeni ile gelmektedir. Yine tüm şikayetler içerisinde 'personel davranışlarındaki olumsuzluk' \%19.3'lük bir oranı bulmaktadır (Kahraman, 2012, s.89). Yani kabaca her beş şikayetten birinde sağllk çalışanının davranışındaki olumsuzluk kaynak olarak görülmektedir. Yine sağlık çalışanı-hasta ilişkisinde yaşanan iletişim sorununu araştıran Uludağ, yaptığ çalışmada; hastaların şikayet içeriklerine göre en büyük sorunun \%40.4 iletişim kaynaklı olduğu ortaya çıkmıştır (2011, s.653). Toplum gözüyle sağlık çal1şanlarına şiddet konusunda çalışma yapan yazarlar çalışmada incelenenlerin yüzde 20'sinin sağlık çalışanının şiddeti hak ettiğini düşündügü tespit etmiştir. Çalışmada, sağlık çalışanının şiddeti hak ettiğini düşünme nedeni olarak en sik hastayla yeterince ilgilenmeme olduğu ortaya çıkmıştır (İlhan vd., 2013, s.10).

Sağlık çalışanına yönelik şiddetle ilgili Ankara Tabip Odası̉nın yaptığı çalışmaları rapor halinde kamuoyuyla paylaşılmıştır. Kapsamlı raporlar olmasına rağ- men, çalışma konusu ile ilgili bölümlerden alıntılar yapılmıştır. 2008 yılında yayınlanan raporda, hasta ve yakınlarında sürekli mağdur edildikleri hissi olduğu, hastalığı ve tedavisiyle ilgili gerekli açıklamaları alamayan hasta ve hasta yakınlarında gerilim fazla olup tepkisel davranışlar doğduğu ve doktorların empatiyi kaybetmeden hastalara yeterli bilgi vermenin çok önemli olduğu (Ankara Tabip Odası Raporu, 2008) tespitleri yer almaktadır. Daha sonra yayınlanan raporda ise hekimler arası ilişkide dayanışmanın zayıfladığı, hekimlerin birbirlerini kötüleyen yorumlar yaptığı, hekimlerin yeterli mesleki donanıma sahip olmadığı, hasta ve hasta yakınlarına olumsuz tavır içinde bulunmalarının şiddeti körüklediğine vurgu yapılmaktadır. Yine raporda toplumda yaşanan kirlenmeden hekimlerin de nasibini belirtilmektedir. Ayıca raporda, hekimlerin iletişim konusunda özel bir eğitimlerinin olmadığı, bu nedenle hastalara yaklaşımda yetersiz kalınmasına neden olabildiği (Ankara Tabip Odası Raporu 2010-2011, 2011, s.24) gibi ciddi, çözüm sunan ifadelerde bulunmaktadır.

\section{Çatışma ve Şiddet}

Hayatın birçok alanında insan ilişkileri çoğu şeyin önünde gelmektedir. Hayatın her alanında yürütülen iş ve işlem her ne olursa olsun insan ilişkileri mutlaka önemlidir. İnsanlar belli ölçüde beklentileri çerçevesinde hareket ederler. Bu nedenle insanlar arasinda ilişkinin nedeninin ne olduğu önemli olmadan çatışma yaşanabilir. Çatışmanın yürütülmesi ve sonuçlanma şekli, çatışmanın kendisinden daha çok ilişkinin yönünü tayin edebilir.

Çatışmalar her zaman zararlı bir sonuca doğru gitmeyebilir. Yakın ilişkilerin, dostlukların meydana gelebilmesi için kişiler kendi benliklerini ortaya koyabilmeleri gerekir. Beraber yaşayan bir şekilde aynı ortamda olmak zorunda kalan kişilerin aralarında çatışma ve sürtüşme çıkması doğaldır. Böyle oldu diye yaşanan bu çatışmalar yüzünden ilişkinin bozulması ise doğal değildir. İlişkilerin bozulması bir yana çatışma ve sürtüşmeden kişiler birbirlerini daha iyi anlayabilmek için fırsatlar yaratmalıdır (Cüceloğlu, 1999, s.195-196).

Bir nedenle iletişim içerisinde bulunan kişiler arasındaki ilişkide hiç çatışma çıkmıyorsa burada bir sorun var demektir. Çatışmanın olmaması, ya bir tarafın öbürü üzerinde güç kullandığı, güçsüz olanın çatışamayacak kadar korkak ve sessiz olduğu ya da ilişkide arabulucu bir rol oynamayı ve boyun eğmeyi öğrendi- 
ği anlamına gelir. İlişkilerde eğer güç kullanılmıyorsa ve işbirliği varsa çatışmaların yüzeye çıkma olasılığ yüksektir. Çatışmaların yüzeysel iletişimi derinleştirmesi için firsat olarak değerlendirilmesi konusunda, yine de iletişim becerisini gerektirmektedir (Gordon ve Edwards, 1997, s.175).

Dış gruba karşı, genellikle karşı tarafın düşmanlığı ve kötü niyetine zorunlu bir yanıt olarak gösterilen düşmanlık, kuşku ve saldırganlık bir önyargı doğurur ve zamanla bu önyargı tarafından ilerletilir. Önyargı düşmanlarda olabilecek herhangi bir erdemin, gerçek ya da hayali kusurlarını abartma eğilimi ile katlanacak doğrudan reddi anlamına gelir. Düşman ilan edilenlerin eylemleri öyle bir yorumlanır ki, her yaptıkları imgelerini daha fazla karartır ve sanki "ne yaparsan yap, ne söylersen söyle, yerden yere vurulacak ve sana karşı kanıt olarak kullanılacaktır" ilkelerine uygun olarak yapılanlarda kötücül dürtüler bulunur. Önyargılar, dış grubun niyetlerinin iyi olabilmesi ya da düşmanlar ne söylemişse onu demiş olabilecekleri ve barış önerilerinin samimi ve gizli dürtülerden arınmış olabilmesi ihtimalinin kabul edilmesini engeller (Bauman, 1999, s.58).

\section{Şiddet ve Saldırganlık}

Bu bölümde genel anlamda şiddet ve nedenleri konuları ele alınacaktır. Riches (1989, s.12) şiddeti belirli eylemleri yapanlardan çok onların tanığı ya da kurbanı olanlara ait bir kelime olarak değerlendirmektedir. Türk Dil Kurumu (2005, s.1866), Büyük Türkçe Sözlüğünde şiddet, "bir hareketin, bir gücün derecesi, sertlik, hız, bir hareketten doğan güç, karşıt görüşte olanlara kaba kuvvet kullanma, kaba güç, duygu veya davranışta aşırılık" şeklinde tanımlamaktadır.

Şiddetle ilgili başka bir yaklaşımı dile getiren Halloran (1983, s.63-84), yaşamın isteklerine yanıt verme olanakları sınırlandırılmış, seçenekleri kısıtlanmış olanlar ve farklı çözüm yolu göremeyenlerin, sonunda şiddete başvurduğunu öne sürmektedir. Uygulayanlara şiddet, toplumda yüksek değer kazanmış nitelikler olan başarının, yükselmenin ve statünün bir seçeneği, hatta tek yolu olarak gelebilmektedir. Riches'e (1989, s.22) göre de, insan bedeninin kıvraklığı ve gücünden gelen imkanların fiziksel nesneleri tahrip edebildiğini bilmek, bir başka insana karşı asgari ölçüde başarılı bir incitme eylemini gerçekleştirmek için yeterlidir.
Şiddetin kendini gösterme şekli olarak daha çok 'saldırganlık' karşımıza çıkmaktadır. Saldırganlık kavramını inceleyerek şiddetin gerçekleşme şekli hakkında daha kapsamlı bilgi vermek daha olasıdır. Şiddetin genetik bir temeli bulunduğu görüşünü sunan araştırmaların bunu daha geniş bir başlık altında 'saldırganlık' kavramı altında tartışıldığı savunan Riches (1989, s.34) den hareketle bu konuya kısaca değinmek yararlı olacaktır. Saldırganlık ve şiddet ilişkisinde Köknel (2000, s.23) saldırgan bir davranış veya şiddet eyleminin, insana ve doğaya çeşitli zararlar verdiğine vurgu yapmaktadır. Köknel'e göre bu zararlar insan üzerinde bedensel, ruhsal ve toplumsal şekilde kendini göstermektedir. Köknel, insana ve doğaya yönelen 'yakmak ve yok etmek' doğrultusundaki bir eylemin amac1, nedeni, beklentisi dikkate alınmadan bu kötü ve zararlı saldırganlık şiddet olarak değerlendirilmesi gerektiğini savunmaktadır.

Türk Dil Kurumu, saldırganlığ "Bireyin kendi düşünce ya da davranışlarını, dıştaki direnmelere karşın zorla karşısındakilere benimsetme çabası" olarak tanımlanmaktadır. Saldırganlığı kişinin bir duygulanım alanı olarak değerlendiren Köknel (2001, s.54) belirtilerin kişiden kişiye farklı değiştiğini öne sürmektedir. Kişinin saldırganlıkla ilintili belirtileri, kendi yapısal özelliklerine göre değişik biçimlerde tezahür edebilmektedir. Bu bağlamda oldukça geniş bir yelpazeye dağılan saldırganlık küçümseyici bir gülüş, mimik, söz olabileceği gibi öldürme ile de sonuçlanabilir. Köknel, artık söze ve mimiğe dayanan saldırganlık belirtilerinin günlük yaşamın sıradan bir parçası haline dönüşmüş olduğunu toplumca büyük oranda içselleştirildiğini belirtmektedir.

\section{Saldırganlık Nedenleri}

Saldırganlık ve nedenlerine dair literatürde epey çalışma ve araştırma bulunmaktadır. Çalışmada literatürde yer alan saldırganlık nedenlerine dair bazı görüşler derlenmiştir. Özellikle sağlık alanına ve çalışma kapsamına girdiği düşünülen nedenlerden bazılarına çalışmada yer verilmiştir. Araştırma bulgular ile literatür bilgilerinin nedenler bazlı bazı yerlerde örtüştüğü görülmektedir.

Çatışmaların istenmeyen hale geldiği olumsuz boyut saldırganlık şeklinde karşılaşılmaktadır. Saldırganlık duygularının temel belirleyicileri arasında rahatsız edilme, saldırı ve engellenme ilk sıraları almaktadır. 
Burada dikkat edilmesi gereken en önemli nokta, engelleyenin niyetine bağlanmayan engellenmelerin, niyete bağlananlar kadar kızgınlık yaratması durumudur. Önemli olanın niyet değil, yapılan eylem olduğu ortaya çıkmaktadır. Genel, yani özgül olamayan uyarılma durumlarına uygun bilişsel etiketler bulunursa sonuç kızgınlık yaşantısı olabilir. Kızgınlık duygusundan başka nedenlerle de saldırganlık davranışları olabilir. Kızgınlık duyguları dışında ki saldırgan davranışın temel belirleyicisi, saldırgan tepkilerin doğrudan pekiştirilmesi, taklit ya da saldırgan davranışın belirli saldırganlık uyarıcılarına koşullanması olabilir (Freedman vd., 1998, s.293). Yazarlar (Gordon ve Edwards, 1997, s.157) kızgınlık durumunu korku, utanma, hayal kırıklı̆̆ı, incinme gibi önceden yaşanmış bir duygunun ardından gelen ikincil bir duygu olarak değerlendirmektedir. Yazarlara göre kızgınlık, karşıdakinin daha önce yaptığı şeyi tekrar yapmaması için onu baskı altında tutmak, cezalandırmak, öç almak, ders vermek amacıyla ve çoğunlukla bilinçli yapılan bir hareket, bir rol olmasının yanında kişi kızgınlığını özel bir amaç için kendisi üretmektedir.

Kişilere karşı gerçekleştirilen engellemeler, öncelikle kişide gerginliğe yol açmakta daha sonra da ise şiddete neden olmaktadır. Herhangi bir istekleri ya da gereksinimleri engellendiği zaman hayvanlarda, çocuklarda ve erginlerde saldırgan davranışlar görülebilmektedir. Bu türden saldırgan davranışlar engellenen amaca, şiddet kullanarak ulaşma yolunda çoğu zaman boşa çıan girişimlerdir (Fromm, 1994, s.20).

Engelleme ve saldırganlık ile ilgili 1939 yılında Yale grubu olarak isimlendirilen Dollard, Doob, Miller, Mowrer ve Sears tarafından kuram geliştirilmiştir. $\mathrm{Bu}$ psikologlara göre engellenme amaç veya hedefe ulaşmanın bloke edilmesi, durdurulmasıdır. Kurama göre engellenmeler arttıkça saldırgan dürtüler de artar ve artan bu saldırgan dürtü açık saldırgan davranışa neden olmaktadır. Yani kurama göre engellenme, herhangi bir şekilde saldırganlığa sürekli yol açar ve saldırganlık sürekli bir engellenmenin sonucu olarak gelişmektedir. Yale grubunun bu görüşü daha sonra Miller ve arkadaşları tarafından eleştirilmiştir. Bunlara göre engellenme, her zaman saldırgan davranışa neden olmamaktadır. Eğer engelleyen güçlü bir kişiyse, burada farklı tepki şekilleri ortaya çıkabilir: Engelleyene karşı saldırgan davranış gösterilmeyebilir, başka bir davranışta bulunabilir veya kişi saldırganlığını bastırabilir (Acet, 2001, s.47).
Bireylerde engellenme duygusu ile şiddet arasında bağlantı bulunmaktadır. Değişik nedenlerden dolayı bireylerce yaşanan kaygı durumu saldırganlığ pekiştirmektedir. Çaresizlik ve güçsüzlük içindeki birey yaşam kaygılarından saldırganlaşabilmektedir. Psikolojik olarak engellendiğini algılayanlar, düş k1rıklığına uğrayanlar, saldırgan davranışlar ve şiddet eğilimleri gösterebilmektedirler (Köknel, 2005, s.38). Sağlık hizmeti sunumunda çok değişik nedenlerden dolayı bireyler farklı engellenmelerle karşılaşmaktadırlar. Bunlardan bazıları sağlık çalışanı kaynaklı, bazıları yerel yöneticilerden, bazıları da ulusal sağlık politikalarından kaynaklı olabilmektedir.

Saldırganlık nedenlerin bir başkası 'misilleme' kavramı şeklinde ele alınmaktadır. Yazar (Riches, 1989, s.45-46) misillemeli şiddet silsilelerinin, rastlantısal olarak veya atlamalı olarak başlayabileceğini dile getirirken, buna gerekçe olarak insanların zarar verici zora maruz kalmamış olsalar bile tecavüze uğradıkları hissine kapılabildiğini ve tecavüze yeltenen olmasa bile kendi tecavüz tecrübelerinden ötürü, ötekileri sorumlu tutabildiğine dikkat çekmektedir. Yine misillemeli şiddet silsileleri bir kez başlayınca, şiddetin derecesi ve tipi dengelenebilir veya değişebilirdir. Her misilleme kendine özgü bir özerklik kazanabilir, her biri hemen önceki incinmeye haklılaştırılmış bir karşlık olarak tasavvur edilir; bununla birlikte, önceki incinme haklılaştırılmış misilleme haline gelebilir. Riches, böyle karşılıklı süren misillemeli silsilelerde mazeretlerin asla sona ermediğini ve artık dengenin kurulabilmesinin zorluğuna değinmektedir. Bunun en önemli nedenin ise her misillemenin biri için denge, öteki için dengesizlik getirmesinin olduğuna vurgu yapmaktadır.

Saldırganlığın davranış boyutuna geçmesinde sosyal modelin (sosyal öğrenme) önemli bir yer tuttuğunu savunan Bandura (1977), çevresel uyarılar arasında sayılabilecek gürültü, 1sı, sosyal ödüller, kalabalık, taklit, aile içinde görülen eksik ve hatalı davranışlarla alevlenen saldırgan düşünce ve ifadelerin, saldırgan davranışın oluşumuna katkıda bulunarak sürdürülmesinde ve güçlenmesinde büyük etken olduğunu belirtmektedir (Karataş, 2002, s.24).

\section{İletişim Davranışı ve Şiddet}

Saldırganlığın şiddete dönüşmemesi için doğru bir iletişimin çözüm olacağı açıktır. Saldırganlıkla ilgili yukarıda bahsi geçen bazı nedenlerin empatik bir ile- 
tişimle, sağlık çalışanları için şiddet uygulanmasının önüne geçmesi veya çok aza indirmesi olasıdır. Doğru teknikle yapılan iletişim çabalarının hasta sağlık çalışanı ilişkisine çok şey katacağı ortadadır. Doğru iletişim çabası, tarafların birbirini anlamasına zemin hazırlaması açısından önemsenmelidir. İletişim kurarken seçilen kelimeler, tonlamalar iletişimin sonucunu belirlemektedir. Yüz yüze olan hasta sağlık çalışanı ilişkisinde kelimeler, tonlamalar, sesin yüksekliği, beden dili gibi iletişim öğeleri oldukça önemlidir.

Doktorların hastalarla sağlıklı bir ilişki kurabilmesi konusunda Örs (1975, s.224), görünüşüne, ifadelerine özen göstermeyen bir doktorun, hastasına beklediği ilgi ve önemi verdiği izlenimini bırakmasının zor olacağını savunmaktadır. Örs, hastasını gerektiği gibi dinlemeyen, onunla iletişime geçmeyen ve görevi nedeniyle bir ilişki içerisinde olduğunu hissettiren bir doktorun sağlıklı bir hasta-doktor ilişkisi kurmasının beklenemeyeceğini belirtmektedir.

İletişimin içinde yer aldığı ortamın psikolojik ve fiziksel özellikleri, gönderilen mesajın yorumlanmasını önemli ölçüde etkilediğine vurgulayan yazar (Cüceloğlu, 1999, s.51) iletişim ortamını iletişimde bulunan kişilere bağlı özellikler, iletişimin içinde oluştuğu ortamın sosyal özellikleri ve iletişimin içinde oluştuğu ortamın fiziksel özellikleri şeklinde incelemektedir.

Sanders’a (1999, s.81) göre şiddetin çözümü hapishaneler dışında başka yerlerde aranmalıdır. Şiddete karşı çözümü Sanders, tüm düşselliğine, tüm uçuculuğuna ve tüm görünmezliğine karşın insan sesinde yani ses verilmiş solukta yattığına vurgu yapmaktadır. Doğuştan getirilen insanın konuşma becerisi bazen neden yeterli çözümü üretmediği sorusuna Sanders, burada kasıtlı olarak anlaşmazlık isteyenlerin kapsam dışı bırakıldığında, anlaşmak için iyi niyetin yetmemesinin bazı nedenlerinin olmasını doğal karşılamaktadır. $\mathrm{Bu}$ konuda yine Sanders'in (1997, s.78), "Hem sözlü hem de yazılı dili elinden alınmış bir kuşak" tabirini kullanarak Amerikan toplumuna dönük bir saptamada bulunarak örneklendirme yapmıştır.

İyi bir iletişim kurmanın zorluğuna dair görüşlerden birisi, iletişim tekniklerini öğretmenin diğer konuları öğretmeye benzemediği gerçeğidir. İletişim teknikleri öğretmede öncelikle, kendine has özellikleri ve yöntemleri vardır. Normal şartlarda nasıl iletişim kurulacağını bilmek de, özel durumlarda hastalarla nasıl konuşulacağını bilmek anlamına gelmemektir. Tipta iletişim, profesyonel bir düzeyde edilmesi gereken profesyonel bir tekniktir (Kurtz vd., 1998, s. xix). $\mathrm{Bu}$ nedenle sağlık çalışanlarının iletişim çabaları, diğer meslek gruplarından daha zor ve yorucudur.

Sağlık çalışanı olarak hastayla etkileşime girmekten korktuğunu farkederseniz olumsuz bazı davranışlar sergilenmeye başlar. Bu davranışlardan bazıları şu şekilde kendini gösterebilir: Sağlık personeli hastaya sinirlenir, yanındayken hastadan sıkılır ve dikkatini işine veremez, son olarak da hastaya hoş göründüğü zamanların az olduğunu anlar (Gordon ve Edwards, 1997, s.146).

Dil kullanımı iletişim çabalarının önemli bir alanını işgal etmektedir. Dili doğru kullanamayan birisinin, karşısındakiyle anlaşması elbette zor olacaktır. Çünkü her dil, onu konuşan insanların gelişiminde kök salmış düşünce biçimlerini ve inanç örüntülerini içeren bir anlam taşımaktadır (Horkmeimer, 1998, s.171). Yine Horkmeimer'ın (1998, s.181) sözcüklerin önemi ve dilin insana sağladıkları ile ilgili görüşü dikkat çekicidir:

"Sözcüklerin değişen içerikleri, tonları ve vurguları, uygarlığımızın tarihinin kayıtlarıdır. Dil, ezilenlerin özlemlerini ve doğanın acılarını yansıtır; mimetik dürtüye boşalma imkanı verir. Bu dürtünün yıkıcı eyleme değil de dilin evrensel ortamına dönüşmesi, nihilist ve gizil güç içeren enerjilerinin karışmaya, uzlaşmaya ve çabalaması anlamına gelir”.

Sağlık hizmetleri sunumunda hasta ve/veya yakınlarıyla iletişim kurmanın gerekliliği kabul görmeye başlamış ve iletişimden kaçışın mümkün olmadığg 1 anlaşılmıştır. Bu gerekliliği yerine getirmek isteyen hekimlerin konuşmaları, bilerek veya bilmeyerek tıbbi ve kurumsal jargonla dolmaya başlamıştı. Bu hekimler önceden bildikleri yeni edindikleri bilimsel terminolojiyi kullanarak hastalarına açıklama yapmaktaydılar. Ayrıca bu ilişkinin doğası gereği asimetrik bir yapı taşımasına rağmen, hastalar hekimlere değişik nedenlerle soru sormaya çekinmekteydiler. $\mathrm{Bu}$ gelişmeler hekim-hasta etkileşiminin niteliğinin istenenden uzak bir duruma gelmesine neden olmaktadır (Okay, 2009, s.27). 
Sağlık hizmeti sunanlar isterlerse tıbbi ve kurumsal jargonu kullanma durumunu çok aza indirebilirler. Yine hastaların soru sormasına imkan sağlayacak şekilde bir iletişim ortamı hazırlayabilirler. Bunları sağlamamanın ciddi bir mazereti olmadığına dair bazı görüşler bulunmaktadır. Tipta iletişim, hizmet verenlerin kişiliğinin getirdiği olumlu ve olumsuzluklardan öte, öğrenilmiş bir seri tekniktir. Hizmet verenleri kişilik özellikleri elbette önemlidir ama iletişim yeteneğinin büyük kısmı öğrenilmiştir ve basit bir şekilde yalnızca genetik yapıya bağlanamaz. İyi bir iletişim kurmaya doğuştan gelen bazı özellikler etkili olmakla birlikte, bu karakteristik özellikler çevre, deneyim ve eğitim sayesinde de gelişip güçlenmektedir (Kurtz vd., 1998, s.11).

Yukarıda sunulan araştırmalar ve literatür ışığında sağlıkta şiddet konusunda hastalar ile sağlık çalışanlarının durumlarını tespit etmek amacıyla çalışmada şu soruların yanıtı aranacaktır:

Araştırma Sorusu 1: Hasta şikayetlerinde sağlık çalışanlarının olumsuz ifadelerinin algılanması ne durumdadır?

Araştırma Sorusu 2: Sağlık çalışanlarının mesleklerinin kullanılan olumsuz ifadelerle ilişkisi var mıdır?

Araştırma Sorusu 3: Sağlıkta şiddet ile sağlık çalışanlarının davranışları arasında bir ilişki var mıdır?

\section{Metodoloji}

Bu araştırma Konya Sağlık Müdürlüğü Hasta Hakları İl Koordinatörlüğü’nün denetiminde olan hasta hakları sistemine yapılan şikayetlerde yer alan olumsuz ifadeleri değerlendirmek amacıyla betimleyici türde gerçekleştirilmiştir. Araştırma evrenini sistemde yer alan 2012 yılında yapılan 663 hasta şikayeti oluşturmaktadır. Evrenin tamamı örneğe alınmış ancak 33’ü hasta hakları kapsamında olmadığ için çalışma d1şında bırakılarak toplam 630 hasta şikayeti üzerinde çalışma tamamlanmıştır. Araştırmada 630 şikayette, daha önceden yapılan ön çalışma sonrası belirlenen belirlenmiş 36 olumsuz ifade taranmıştır. Bunlardan 27'si "sağlık çalışanlarından", 4'ü "sağlık kuruluşlarının durumundan, 5’i ise "hastaların kendi durum- larını tariflerinden" oluşmaktadır. Araştırmada, şikayetlerde geçen kelimeler doğru olarak değil, hasta iddiaları olarak değerlendirilmiştir. İfadeler aynen alınmış olup, benzer anlama gelecek ifadeler çalışma dışında bırakılmıştır. Çalışmada, hastaların şikayetlerinde sağlık çalışanlarından ve sağlık kurumlarından kaynaklanan olumsuz ifadelerin varlığının yanı sıra kendilerini tanımlamaya dönük olumsuz ifadelerin kullanılma durumları incelenmiştir.

$\mathrm{Bu}$ amaçla belirlenen olumsuz ifadeler ile sağlık çalişanlarının meslekleri ve sosyo-demografik kriterlerini kapsayan bir form kullanılmıştır. Araştırmadan önce Sağlık Bakanlığı’ndan yazılı izin alınmıştır. Olumsuz ifadeler kodlandıktan sonra, istatistik paket programına aktarılarak sayısallaştırılmıştır. Veriler, Evet (1), Hayır (2) şeklinde kodlandığından dolayı değerlendirmelerin yönü ters olmuştur. Verilerin analizinde, tanımlayıcı istatistik için frekans dağılımı ve ortalama, bağımlı ve bağımsız değişkenleri değerlendirmek için $t$ testi, tek yönlü varyans analiz yöntemleri kullanılmıștır.

\section{Bulgular}

Araştırmada 630 hasta şikayeti taranmış olup bulgular aşağıda tablo şeklinde sunulmaktadır.

Araştırmada yer alan hasta şikayetleri olumsuz ifadeler bakımından incelendiğinde (tablo 1), 630 şikayette toplam 917 olumsuz ifadenin geçtiği görülmektedir. En sık geçen ilk 5 ifade ise 'bekledim-bekletti' (102 kez), 'azarladi' (76 kez), 'ilgisiz' (75 kez), 'mağdur(um) etti' (75 kez) ve 'hakaret etti' (58 kez) olduğu görülmektedir. En az geçen ifadeler ise 'yalvardım' (5 kez), 'defol' (4 kez), 'önyargılı davrandı' (2 kez), 'tehdit etti' ve 'bakımsız' ise (1 kez) şeklindedir.

Toplam 917 olumsuz ifadenin, sağlık çalışanlarından kaynaklı (27 ifade) $742 \mathrm{kez}(\% 80,9)$, hastaların kendi durumlarını tariflerinden (mağdur(um)-etti, hakkımız yeniyor, memnun değilim, endişeliyim, yalvardım) $118 \mathrm{kez}(\% 12,9)$ ve sağlık kuruluşlarının durumundan (böyle olmamalı, kötü, pis, bakımsız) 57 kez $(\% 6,2)$ geçtiği görülmektedir. Hasta iddialarına bakıldığında olumsuz ifadelerde sağlık çalışanlarının payının önemli oranda yüksekliği ortadadır. 
Tablo 1. Hasta Şikayetlerinde Yer Alan Olumsuz Ifadelerin Dağılımı

\begin{tabular}{|c|c|c|c|c|c|c|c|c|c|}
\hline No & $\begin{array}{l}\text { KELIMMELER- } \\
\text { IFADELER }\end{array}$ & SAYI & YÜZDE & Doktor & $\begin{array}{c}\text { Diş } \\
\text { Hekimi }\end{array}$ & $\begin{array}{c}\text { Hemşire- } \\
\text { Ebe- } \\
\text { Sağlık } \\
\text { Memuru }\end{array}$ & $\begin{array}{c}\text { Tıbbi. } \\
\text { Sek.- } \\
\text { Bilgi } \\
\text { İşlem }\end{array}$ & Güvenlik & $\begin{array}{c}\text { Diğer } \\
\text { Personel }\end{array}$ \\
\hline 1 & $\begin{array}{l}\text { Bekledim- } \\
\text { Bekletti }\end{array}$ & 102 & 15,4 & 47 & 9 & 6 & 14 & 2 & 24 \\
\hline 2 & Azarlad1 & 76 & 11,5 & 44 & 4 & 10 & 8 & 1 & 9 \\
\hline 3 & İlgisiz & 75 & 11,3 & 39 & 10 & 13 & 1 & 0 & 12 \\
\hline 4 & Măgdur(um)-etti & 75 & 11,3 & 28 & 9 & 5 & 5 & 1 & 27 \\
\hline 5 & Hakaret etti & 58 & 8,7 & 26 & 11 & 5 & 4 & 3 & 9 \\
\hline 6 & Bağırdı & 57 & 8,6 & 22 & 10 & 10 & 5 & 4 & 6 \\
\hline 7 & Kovdu & 43 & 6,5 & 18 & 5 & 4 & 9 & 3 & 4 \\
\hline 8 & Bilgi vermedi & 41 & 6,2 & 12 & 7 & 2 & 8 & 0 & 12 \\
\hline 9 & $\begin{array}{l}\text { Umursamad1 - } \\
\text { Sorumsuz }\end{array}$ & 31 & 4,7 & 14 & 3 & 3 & 2 & 0 & 9 \\
\hline 10 & $\begin{array}{l}\text { Acı çektim- } \\
\text { çektirdi }\end{array}$ & 30 & 4,5 & 14 & 10 & 4 & 0 & 0 & 2 \\
\hline 11 & $\begin{array}{l}\text { Küçük düşürdü- } \\
\text { Aşağıladı }\end{array}$ & 26 & 3,9 & 18 & 1 & 2 & 1 & 1 & 3 \\
\hline 12 & Saygisız davrandı & 25 & 3,8 & 13 & 0 & 1 & 5 & 2 & 4 \\
\hline 13 & Kötü davrandı & 24 & 3,6 & 10 & 2 & 7 & 2 & 1 & 2 \\
\hline 14 & Böyle Olmamalı & 23 & 3,5 & 6 & 0 & 0 & 1 & 1 & 15 \\
\hline 15 & $\begin{array}{l}\text { Hakkımız } \\
\text { yeniyor }\end{array}$ & 23 & 3,5 & 13 & 0 & 2 & 5 & 1 & 2 \\
\hline 16 & Kaba davrand 1 & 22 & 3,3 & 8 & 3 & 1 & 7 & 0 & 3 \\
\hline 17 & Kovdu & 22 & 3,3 & 11 & 4 & 3 & 3 & 0 & 1 \\
\hline 18 & Sert davrand 1 & 22 & 3,3 & 9 & 1 & 3 & 3 & 2 & 4 \\
\hline 19 & $\underline{\text { Kötü }}$ & 20 & 3 & 5 & 4 & 1 & 0 & 1 & 9 \\
\hline 20 & Yardımcı olmadı & 18 & 2,7 & 5 & 1 & 5 & 4 & 0 & 3 \\
\hline 21 & Tersledi & 15 & 2,3 & 8 & 0 & 3 & 3 & 0 & 1 \\
\hline 22 & $\underline{\mathrm{Pis}}$ & 13 & 2 & 0 & 3 & 3 & 0 & 0 & 7 \\
\hline 23 & İyi davranmadı & 9 & 1,4 & 3 & 5 & 1 & 0 & 0 & 0 \\
\hline 24 & Nezaketsiz & 8 & 1,2 & 5 & 2 & 1 & 0 & 0 & 0 \\
\hline 25 & Memnun değilim & 8 & 1,2 & 3 & 1 & 0 & 0 & 0 & 4 \\
\hline 26 & Ayrımcılık yaptı & 7 & 1,1 & 4 & 0 & 0 & 2 & 0 & 1 \\
\hline 27 & Anlayışsız & 7 & 1,1 & 5 & 0 & 0 & 0 & 0 & 2 \\
\hline 28 & Endişeliyim & 7 & 1,1 & 3 & 0 & 2 & 0 & 0 & 2 \\
\hline 29 & Vicdansız & 6 & 0,9 & 4 & 0 & 0 & 0 & 0 & 2 \\
\hline 30 & Adaletsiz & 6 & 0,9 & 2 & 0 & 1 & 0 & 0 & 3 \\
\hline 31 & Laubali davrand & 5 & 0,8 & 2 & 0 & 1 & 0 & 0 & 2 \\
\hline 32 & Yalvardim & 5 & 0,8 & 2 & 0 & 2 & 0 & 0 & 1 \\
\hline 33 & Defol & 4 & 0,6 & 3 & 1 & 0 & 0 & 0 & 0 \\
\hline 34 & $\begin{array}{l}\text { Önyarg1lı } \\
\text { davrand } 1\end{array}$ & 2 & 0,3 & 0 & 0 & 2 & 0 & 0 & 0 \\
\hline 35 & Tehdit etti & 1 & 0,2 & 1 & 0 & 0 & 0 & 0 & 0 \\
\hline \multirow[t]{2}{*}{36} & $\frac{\text { Bakımsız }}{\text { Kuruluşu) }}($ Sağlık & 1 & 0,2 & 0 & 0 & 0 & 0 & 0 & 1 \\
\hline & Toplam & 917 & & 407 & 106 & 103 & 92 & 23 & 186 \\
\hline
\end{tabular}


Tablo 2. Hasta Şikayetlerinde Yer Alan Sağlık Çalışanlarının Meslekleri

\begin{tabular}{|r|l|c|c|c|}
\hline & Meslek-Görev & Sayı & Yüzde & $\begin{array}{c}\text { Geçerli } \\
\text { Yüzde }\end{array}$ \\
\hline 1 & Doktor & 267 & 40,3 & 42,4 \\
\hline 2 & Diş hekimi & 73 & 11 & 11,6 \\
\hline 3 & Hemşire-Ebe-Sağlık memuru & 67 & 10,1 & 10,6 \\
\hline 4 & Tibbi sekreter-Bilgi işlem çalışanı & 49 & 7,4 & 7,8 \\
\hline 5 & Güvenlik personeli & 13 & 2 & 2,1 \\
\hline 6 & Diğer personel & 161 & 24,3 & 25,6 \\
\hline & Toplam & 630 & 95 & 100 \\
\hline & Hasta hakları şikayeti değil & 33 & 5 & \\
\hline & Genel toplam & 663 & & \\
\hline
\end{tabular}

Tablo 2'ye göre en çok doktorlar (\% 42,4) hasta şikayetine konu olmuştur. Doktorları birbirine yakın oranlarda diş hekimi $(\%$ 11,6) ve hemşire-ebe-sağlik memuru $(\%$ 10,6) grubu takip etmektedir. Şikayetlerin önemli bir kesimi de (\% 25,6) diğer çalışanlara dönük olarak gerçekleştiği görülmektedir.

Tablo 3. Sağlık Çalışanlarının Meslekleri ile Hasta Şikayetlerinde Yer Alan Ifadelerin Dağılımı

\begin{tabular}{|c|c|}
\hline \multirow[t]{2}{*}{ Değişkenler } & İfadeler Ortalaması \\
\hline & Ortalama \pm SS \\
\hline \multicolumn{2}{|l|}{ Bağırdı } \\
\hline 1- Doktor & $1,9176 \pm 0,27548$ \\
\hline 2- Hemşire-Ebe-Sağlık Memuru & $1,8507 \pm 0,35903$ \\
\hline 3- Tıbbi Sekreter - Bilgi İşlem Personeli & $1,8980 \pm 0,30584$ \\
\hline 4- Güvenlik personeli & $1,6923 \pm 0,48038$ \\
\hline 5- Diğer & $1,9627 \pm 0,19001$ \\
\hline 6- Diş Hekimi & $1,8630 \pm 0,34621$ \\
\hline \multirow[t]{2}{*}{ Onemlilik testi } & $\mathrm{F}=3,674$ \\
\hline & $\mathrm{p}=0,001$ \\
\hline \multicolumn{2}{|l|}{ Azarladı } \\
\hline 7- Doktor & $1,8352 \pm 0,37169$ \\
\hline 8- Hemşire-Ebe-Sağlık Memuru & $1,8507 \pm 0,35903$ \\
\hline 9- Tıbbi Sekreter - Bilgi İşlem Personeli & $1,8367 \pm 0,37344$ \\
\hline 10- Güvenlik personeli & $1,9231 \pm 0,27735$ \\
\hline 11- Diğer & $1,9441 \pm 0,23045$ \\
\hline 12- Diş Hekimi & $1,9452 \pm 0,22915$ \\
\hline \multirow[t]{2}{*}{ Önemlilik testi } & $\mathrm{F}=3,219$ \\
\hline & $p=0,007$ \\
\hline
\end{tabular}


Tablo 3. Sağlık Çalışanlarının Meslekleri ile Hasta Şikayetlerinde Yer Alan Ifadelerin Dağılımı (Devamı)

\begin{tabular}{|c|c|}
\hline Kaba Davrandı & \\
\hline 1- Doktor & $1,9700 \pm 0,17080$ \\
\hline 2- Hemşire-Ebe-Sağlık Memuru & $1,9851 \pm 0,12217$ \\
\hline 3- Tıbbi Sekreter - Bilgi İşlem Personeli & $1,8571 \pm 0,35355$ \\
\hline 4- Güvenlik personeli & $2,0000 \pm 0,00000$ \\
\hline 5- Diğer & $1,9814 \pm 0,13565$ \\
\hline 6- Diş Hekimi & $1,9589 \pm 0,19989$ \\
\hline Önemlilik testi & $\mathrm{F}=4,039$ \\
\hline & $\mathrm{p}=0,001$ \\
\hline Saygisız Davrandı & \\
\hline 7- Doktor & $1,9513 \pm 0,21562$ \\
\hline 8- Hemşire-Ebe-Sağlık Memuru & $1,9851 \pm 0,12217$ \\
\hline 9- Tibbi Sekreter - Bilgi İşlem Personeli & $1,8980 \pm 0,30584$ \\
\hline 10- Güvenlik personeli & $1,8462 \pm 0,37553$ \\
\hline 11- Diğer & $1,9752 \pm 0,15614$ \\
\hline 12- Diş Hekimi & $2,0000 \pm 0,00000$ \\
\hline Önemlilik testi & $\mathrm{F}=3,052$ \\
\hline & $\mathrm{p}=0,010$ \\
\hline Acı Çektim-Çektirdi & \\
\hline 13- Doktor & $1,9476 \pm 0,22332$ \\
\hline 14- Hemşire-Ebe-Sağlık Memuru & $1,9403 \pm 0,23872$ \\
\hline 15- Tibbi Sekreter - Bilgi İşlem Personeli & $2,0000 \pm 0,00000$ \\
\hline 16- Güvenlik personeli & $2,0000 \pm 0,00000$ \\
\hline 17- Diğer & $1,9876 \pm 0,11111$ \\
\hline 18- Diş Hekimi & $1,8630 \pm 0,34621$ \\
\hline Önemlilik tecti & $\mathrm{F}=4,241$ \\
\hline 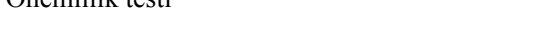 & $\mathrm{p}=0,001$ \\
\hline Bilgi vermedi & \\
\hline 19- Doktor & $1,9551 \pm 0,20757$ \\
\hline 20- Hemşire-Ebe-Sağlık Memuru & $1,9701 \pm 0,17146$ \\
\hline 21- Tıbbi Sekreter - Bilgi İşlem Personeli & $1,8367 \pm 0,37344$ \\
\hline 22- Güvenlik personeli & $2,0000 \pm 0,0000$ \\
\hline 23- Diğer & $1,9255 \pm 0,26346$ \\
\hline 24- Diş Hekimi & $1,9041 \pm 0,29648$ \\
\hline Önemlilik tecti & $\mathrm{F}=2,669$ \\
\hline 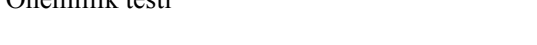 & $\mathrm{p}=0,021$ \\
\hline İyi Davranmadı & \\
\hline 25- Doktor & $1,9888 \pm 0,10560$ \\
\hline 26- Hemşire-Ebe-Sağlık Memuru & $1,9851 \pm 0,12217$ \\
\hline 27- Tıbbi Sekreter - Bilgi İşlem Personeli & $2,0000 \pm 0,00000$ \\
\hline 28- Güvenlik personeli & $2,0000 \pm 0,0000$ \\
\hline 29- Diğer & $2,0000 \pm 0,0000$ \\
\hline 30- Diş Hekimi & $1,9315 \pm 0,25434$ \\
\hline Önemlilik testi & $F=3,806$ \\
\hline & $\mathrm{p}=0,002$ \\
\hline
\end{tabular}


Tablo 3. Sağlık Çalışanlarının Meslekleri ile Hasta Şikayetlerinde Yer Alan Ifadelerin Dağılımı (Devamı)

\begin{tabular}{|c|c|}
\hline \multicolumn{2}{|l|}{ Kötü Davrand1 } \\
\hline 1- Doktor & $1,9625 \pm 0,19023$ \\
\hline 2- Hemşire-Ebe-Sağlık Memuru & $1,8955 \pm 0,30819$ \\
\hline 3- Tıbbi Sekreter - Bilgi İşlem Personeli & $1,9592 \pm 0,19991$ \\
\hline 4- Güvenlik personeli & $1,9231 \pm 0,27735$ \\
\hline 5- Diğer & $1,9876 \pm 0,1111$ \\
\hline 6- Diş Hekimi & $1,9726 \pm 0,16437$ \\
\hline \multirow{2}{*}{ Önemlilik testi $(F=2,367)(p=, 038)$} & $\mathrm{F}=2,367$ \\
\hline & $\mathrm{p}=0,038$ \\
\hline \multicolumn{2}{|l|}{ Önyarg1lı Davrandı } \\
\hline 7- Doktor & $2,0000 \pm 0,00000$ \\
\hline 8- Hemşire-Ebe-Sağlık Memuru & $1,9701 \pm 0,17146$ \\
\hline 9- T1bbi Sekreter - Bilgi İșlem Personeli & $2,0000 \pm 0,00000$ \\
\hline 10- Güvenlik personeli & $2,0000 \pm 0,00000$ \\
\hline 11- Diğer & $2,0000 \pm 0,00000$ \\
\hline 12- Diş Hekimi & $2,0000 \pm 0,00000$ \\
\hline \multirow{2}{*}{ Önemlilik testi } & $\mathrm{F}=3,432$ \\
\hline & $\mathrm{p}=0,005$ \\
\hline \multicolumn{2}{|l|}{ Yardımcı Olmadı } \\
\hline 13- Doktor & $1,9813 \pm 0,13581$ \\
\hline 14- Hemşire-Ebe-Sağlık Memuru & $1,9254 \pm 0,26477$ \\
\hline 15- T1bbi Sekreter - Bilgi İșlem Personeli & $1,9184 \pm 0,27664$ \\
\hline 16- Güvenlik personeli & $2,0000 \pm 0,00000$ \\
\hline 17- Diğger & $1,9814 \pm 0,13565$ \\
\hline 18- Diş Hekimi & $1,9863 \pm 0,11704$ \\
\hline \multirow{2}{*}{ Önemlilik testi } & $\mathrm{F}=2,539$ \\
\hline & $\mathrm{p}=0,027$ \\
\hline \multicolumn{2}{|l|}{ İlgisiz } \\
\hline 19- Doktor & $1,8539 \pm 0,35384$ \\
\hline 20- Hemşire-Ebe-Sağlık Memuru & $1,8060 \pm 0,39844$ \\
\hline 21- Tıbbi Sekreter - Bilgi İşlem Personeli & $1,9796 \pm 0,14286$ \\
\hline 22- Güvenlik personeli & $2,0000 \pm 0,0000$ \\
\hline 23- Diğer & $1,9255 \pm 0,26346$ \\
\hline 24- Diş Hekimi & $1,8630 \pm 0,34621$ \\
\hline \multirow{2}{*}{ Önemlilik testi } & $\mathrm{F}=3,048$ \\
\hline & $\mathrm{p}=0,010$ \\
\hline \multicolumn{2}{|l|}{ Böyle Olmamalı } \\
\hline 25- Doktor & $1,9775 \pm 0,14846$ \\
\hline 26- Hemşire-Ebe-Sağlık Memuru & $2,0000 \pm 0,00000$ \\
\hline 27- Tıbbi Sekreter - Bilgi İşlem Personeli & $1,9796 \pm 0,14286$ \\
\hline 28- Güvenlik personeli & $1,9231 \pm 0,27735$ \\
\hline 29- Diğger & $1,9068 \pm 0,29157$ \\
\hline 30- Diș Hekimi & $2,0000 \pm 0,00000$ \\
\hline \multirow{2}{*}{ Önemlilik testi } & $\mathrm{F}=4,613$ \\
\hline & $\mathrm{p}=0,000$ \\
\hline
\end{tabular}


Tablo 3. Sağlık Çalışanlarının Meslekleri ile Hasta Şikayetlerinde Yer Alan Ifadelerin Dağılımı (Devamı)

\begin{tabular}{|r|c|}
\hline Hakkımız Yeniyor & $1,9513 \pm 0,21562$ \\
1- Doktor & $1,9701 \pm 0,17146$ \\
2- Hemşire-Ebe-Sağlık Memuru & $1,8980 \pm 0,30584$ \\
3- Tıbbi Sekreter - Bilgi İşlem Personeli & $1,9231 \pm 0,27735$ \\
4- Güvenlik personeli & $1,9876 \pm 0,11111$ \\
5- Diğer & $2,0000 \pm 0,00000$ \\
6- Diş Hekimi & $\mathrm{F}=2,675$ \\
\hline Önemlilik testi & $\mathrm{p}=0,021$ \\
\hline
\end{tabular}

Hakkında başvuru yapılanların meslekleri ile olumsuz ifadeler arasında ANOVA analizi yapılmış, 13 ifade ile anlamlı bir fark bulunmuştur. Geri kalan olumsuz ifadeler ile sağlık çalışanlarının arasında anlamlı bir fark bulunmamıştır. Analize göre meslekler ile 'bağırdı' ifadesi arasında anlamlı $(\mathrm{F}=3,674)(\mathrm{p}=, 001)$ bir fark bulunmuştur. Buna göre 'bağırdı' ifadesinde Güvenlik en yüksek ortalamayı alırken bunu sırasıyla Hemşire-Ebe-Sağlık Memuru, Diş Hekimi, Tibbi Sekreter-Bilgi İşlem Personeli, Doktor ve Diğer Personel izlemektedir.

Meslekler ile 'azarladi' ifadesi arasında anlamlı ( $\mathrm{F}=$ $3,219)(\mathrm{p}=, 007)$ bir fark bulunmuştur. Buna göre 'azarladı' ifadesinde Doktor en yüksek ortalamayı alırken bunu sırasıyla Tibbi Sekreter-Bilgi İşlem Personeli, Hemşire-Ebe-Sağlık Memuru, Güvenlik, Diğer Personel ve Diş Hekimi izlemektedir. Meslekler ile 'kaba davrand' ifadesi arasinda anlamlı $(\mathrm{F}=4,039)$ $(\mathrm{p}=$,001) bir fark bulunmuştur. Buna göre 'kaba davrandı' ifadesinde Tibbi Sekreter-Bilgi İşlem Personeli en yüksek ortalamayı alırken, bunu sırasıyla, Diş Hekimi, Doktor, Diğer Personel, Hemşire-Ebe-Sağlık Memuru ve Güvenlik izlemektedir.

Meslekler ile 'saygısız davrandi' ifadesi arasında anlamlı $(\mathrm{F}=3,052)(\mathrm{p}=, 010)$ bir fark bulunmuştur. Buna göre 'saygısız davrandı' ifadesinde Güvenlik en yüksek ortalamayı alırken bunu sırasıyla Tibbi Sekreter-Bilgi İșlem Personeli, Doktor, Diğer Personel, Hemşire-Ebe-Sağlık Memuru ve Diş Hekimi izlemektedir. Meslekler ile 'acı çektim-çektirdi' ifadesi arasında anlamlı $(\mathrm{F}=4,241)(\mathrm{p}=, 001)$ bir fark bulunmuştur. Buna göre 'acı çektim-çektirdi' ifadesinde Diş Hekimi en yüksek ortalamayı alırken bunu sırasılya Hemşire-Ebe-Sağlık Memuru, Doktor, Diğer Personel, Tibbi Sekreter-Bilgi İşlem Personeli ve Güvenlik izlemektedir.
Meslekler ile 'bilgi vermedi' ifadesi arasında anlamlı $(\mathrm{F}=2,669)(\mathrm{p}=, 021)$ bir fark bulunmuştur. Buna göre 'bilgi vermedi' ifadesinde Tibbi Sekreter-Bilgi İşlem Personeli en yüksek ortalamayı alırken bunu sırasıyla, Diş Hekimi, Diğer Personel, Doktor, HemşireEbe-Sağlık Memuru ve Güvenlik izlemektedir. Meslekler ile 'iyi davranmadi' ifadesi arasinda anlamlı $(\mathrm{F}=3,806)(\mathrm{p}=, 002)$ bir fark bulunmuştur. Buna göre 'iyi davranmadı' ifadesinde Diş Hekimi en yüksek ortalamayı alırken bunu sırasıyla, Hemşire-Ebe-Sağlık Memuru, Doktor, Güvenlik, Tibbi Sekreter-Bilgi İşlem Personeli ve Diğer Personel izlemektedir. Burada son üç meslek grubunun ortalaması aynı olup ortalaması en alt düzeydedir.

Meslekler ile 'kötü davrandı' ifadesi arasında anlam$l_{1}(\mathrm{~F}=2,367)(\mathrm{p}=, 038)$ bir fark bulunmuştur. Buna göre 'kötü davrandı' ifadesinde Hemşire-Ebe-Sağlık Memuru en yüksek ortalamayı alırken bunu sırasıyla Güvenlik, Tibbi Sekreter-Bilgi İșlem Personeli, Doktor, Diş Hekimi ve Diğer Personel izlemektedir. Meslekler ile 'ön yargilı davrandı' ifadesi arasinda anlamlı $(\mathrm{F}=3,432)(\mathrm{p}=, 005)$ bir fark bulunmuştur. Buna göre 'ön yargılı davrandı' ifadesinde Hemşire-Ebe-Sağlık Memuru en yüksek ortalamayı alırken, diğer meslek grupları ise en düşük ortalamada kalmıştır. Daha açık bir deyişle 'Hemşire-Ebe-Sağlık Memuru' grubu dışında diğer hiç sağlık çalışanına 'ön yargılı davrandı' ifadesi kullanılmamış olması dikkat çekicidir. Meslekler ile 'yardımcı olmadı' ifadesi arasinda anlamlı $(\mathrm{F}=2,539)(\mathrm{p}=, 027)$ bir fark bulunmuştur. Buna göre 'yardımcı olmadı' ifadesinde Tibbi Sekreter-Bilgi İşlem Personeli en yüksek ortalamayı alırken bunu sırasıyla Hemşire-Ebe-Sağlık Memuru, Doktor, Diğer Personel, Diş Hekimi ve Güvenlik izlemektedir. Meslekler ile 'ilgisiz' ifadesi arasında anlamlı $(\mathrm{F}=3,048)$ $(\mathrm{p}=, 010)$ bir fark bulunmuştur. Buna göre 'ilgisiz' ifadesinde Hemşire-Ebe-Sağlık Memuru en yüksek or- 
talamayı alırken bunu sırasıyla Doktor, Diş Hekimi, Diğer Personel, Tibbi Sekreter-Bilgi İşlem Personeli ve Güvenlik izlemektedir.

Meslekler ile 'böyle olmamalı' ifadesi arasında anlam$l_{1}(\mathrm{~F}=4,613)(\mathrm{p}=, 000)$ bir fark bulunmuştur. Buna göre 'böyle olmamalı' ifadesinde Diğer Personel en yüksek ortalamayı alırken bunu sırasıyla Güvenlik, Doktor, Tibbi Sekreter-Bilgi İşlem Personeli takip ederken, Hemşire-Ebe-Sağlık Memuru ve Diş Hekimi grubu ise en düşük aynı ortalamayı almıştır. Meslekler ile 'hakkımız yeniyor' ifadesi arasında anlamlı $(\mathrm{F}=2,675)(\mathrm{p}=, 021)$ bir fark bulunmuştur. Buna göre 'hakkımız yeniyor' ifadesinde Tibbi Sekreter-Bilgi İşlem Personeli en yüksek ortalamayı alırken bunu sırasıyla Güvenlik, Doktor, Hemşire-Ebe-Sağlık Memuru, Diğer Personel ve Diş Hekimi izlemektedir.

\section{Sonuç}

Sağlık çalışanlarının hasta ve yakınlarıyla kuracağı iyi iletişim, tanı ve tedavi süreçlerini ciddi şekilde etkileme gücüne sahiptir. Toplumun her kesiminden kişilerin hasta olacağı düşünüldüğünde iletişimi doğru kurmak ve yönetmek sağlık çalışanlarının görevidir. Sağlık çalışanın sadece mesleki alanda yeterliliği, doğru iletişimi sağlamak için yetersiz kalabilir. Bu nedenle iletişime dair eğitim süreçleri, hem mezuniyet öncesi hem de mezuniyet sonrasında günün koşullarına uygun şekilde devam etmelidir.

Şiddet, insanlığın varlı̆̆ı ile beraber ortaya çıkan toplumlar ve kültürler arası farklılık gösterebilen evrensel bir olgudur. Her geçen gün hayatın birçok alanında şiddet ile karşı karşıya kalınmaktadır. Bu açıdan bakıldığında sağlıkta şiddetin görülmesi, hayatın olağan akışının bir parçasıdır. Son yıllarda özellikle sağlıkta şiddetin daha fazla görülmesi ve sağlık çalışanını öldürmeye kadar uzanan bir kapsama dönüşmesi, meselenin üzerinde daha ciddi durmayı gerektirmektedir. Yine sağlı hizmetinin doğrudan kişinin yaşamsal alanını kapsaması ve onların sağlığı düzeltmeye çalışması gibi birçok nedenden dolayı kutsaldır. Savaşlarda bile sağlık hizmeti veren kişiler ve yerlerin dokunulmazlığa varan konumları düşünüldüğünde, sağlık çalışanına şiddet vakalarının anlaşılmasını zorlaştırmaktadır.

Sağllkta şiddetin nedenlerine ilişkin çalışmalar gözden geçirildiğinde çoğunlukla, hasta ve yakınların- dan kaynaklı nedenler üzerinde durulduğu görülmektedir. Şiddetin evrensel nedenlerine bakıldığında belli bir kısmının karşıdakine bir şekilde tepki vermek olduğu görülmektedir. Engellenme de önemli bir tepki gösterme nedeni olarak araştırmacılarca öne sürülmektedir. Bu bağlamda bakıldığında şiddetin sağlık çalışanlarından kaynaklı yönü ile sağlık sistemi nedenli kaynakları yeterince şiddete neden olarak değerlendirilip çalışmalara dahil edilmemiştir. $\mathrm{Bu}$ nedenle sağlıkta şiddetin önlenmesine dair önemli adımlar atılma konusunda ilerleme kaydetme şansı düşük olacaktır.

Araştırma bulgularına bakıldığında, 630 şikayette toplam 917 olumsuz ifadenin geçtiği görülmektedir. Mesleklere göre en çok $(\% 42,4)$ doktorların şikayet edildiği bulunmuştur. En sık 'bekledim-bekletti' (102 kez) ifadesinin geçmesi ise sağlık sistemini bütününü ilgilendirmektedir. Bunun yanında 'azarladi' (76 kez), 'ilgisiz' (75 kez), ve 'hakaret etti' (58 kez) ise doğrudan sağlık çalışanlarını ilgilendirirken 'mağdur(um) etti' (75 kez) hem sağlık çalışanı hem de sağlık sistemiyle bağlantılıdır. Olumsuz ifadelerin Yine 'azarladı' ifadesinde doktorlar; 'bağırdı', 'saygısız davrandı' ifadelerinde güvenlik personeli; 'kaba davrandi', 'bilgi vermedi', 'yardımcı olmadi, 'hakkımız yeniyor' ifadelerinde tıbbi sekreter-bilgi işlem personeli; 'kötü davrandı', 'ön yargılı davrandı' ifadelerinde hemşire-ebe-sağlık memuru; 'iyi davranmadı', 'acı çektim-çektirdi' ifadelerinde ise diş hekimleri en yüksek ortalamayı almıştır.

Araştırmada hasta şikayetlerinden elde edilen verilere bakıldığında hastaların olumsuz algılara sahipliği görülmektedir. Şikayetlerde geçen sağlık çalışanlarından kaynaklı ifadeler, elbette ispatlanmamış hasta görüşleridir ama hasta algısını belirlemek için önemlidir. Bu nedenle sağlıkta şiddeti önleme çalışmalarında sağlık sisteminin ve çalışanlarının iletişim tutum ve davranışları gözden geçirilmelidir. Konjonktürel çözüm arayışları, cezaları artırmaya dönük yaklaşımlar ve sağlık çalışanlarının duymasından hoşlanacağı öneriler sunmak, sağlıkta şiddete bir çare olamayacaktır. Sağlıkta şiddetle ilgili farklı açıları içine alan derinlikli çalışmalar yapılması, sağlık sisteminin daha işler hale gelmesine neden olacaktır. Hem hizmet verenler hem de hizmet alanların karşıllıklı memnuniyetini gözeten bir çalışma ortamı için, düzeltici yapısal yenilikler getirilmeli ve sağlık personeli hasta ilişkisi geliştirilmelidir. 


\section{Kaynakça}

Acet, M. (2001). Futbol Seyircisini Fanatik ve Saldirgan Olmaya Yönelten Sosyal Faktörler, (Yayımlanmamıș Doktora Tezi), Gazi Üniversitesi/Sağlık Bilimleri Enstitüsü, Ankara.

Ankara Tabip Odası (2008). "Hekimlere ve Sağlık Çalışanlarına Yönelik Şiddet Raporu”, http://www.ttb. org.tr/siddet/images/file/atoforum.pdf.

Ankara Tabip Odası (2011). "Hekimlere ve Sağlık Çalışanlarına Yönelik Şiddet Raporu 2010-2011” http:// static.ato.org.tr/fs/4f50993567cde95526000000/ mucize_rapor.pdf .

Aydın, M. (2008). Isparta-Burdur Sağlık Çalışanlarına Yönelik Şiddet ve Şiddet Algısı, TTB Isparta-Burdur Tabip Odası.

Bauman, Z. (1999). Sosyolojik Düşünmek, Abdullah Yllmaz (Çev.). İstanbul: Ayrıntı.

Cüceloğlu, D. (1999). Yeniden İnsan İnsana. İstanbul: Remzi.

Freedman, J L., Sears, D O \& Carlsmith, J. M. (1998). Sosyal Psikoloji. Ali Dönmez (Çev.), Ankara: İmge.

Fromm, E. (1994). Sevginin ve Şiddetin Kaynağı. Yurdanur Salman ve Nalan İçten (Çev.), İstanbul: Payel.

Gordon, T. \& Edwards, W. S. (1997). Doktor-Hasta Issbirliği. Emel Aksay (Çev.), İstanbul: Sistem.

Halloran D., J. (1983). Kitle İletişimi Şiddetin Belirtisi mi Yoksa Nedeni mi? Ruşen Keleş (Çev.), Ankara: Türk Sosyal Bilimler Derneği.

Horkmeimer, M. (1998). Akıl Tutulması. Orhan Koçak (Çev.), İstanbul: Metis.

İlhan, M. N., Çakır, M., Tunca, Z. M., Avcı, E., Çetin, E., Aydemir, Ö., Tezel, A. \& Bumin, M. A. (2013), Toplum Gözüyle Sağlık Çalışanlarına Şiddet: Nedenler, Tutumlar, Davranışlar, Gazi Medical Journal (GMJ). 24 (1). 5-10.
Kahraman, N. (2012). Ege Üniversitesi Tip Fakültesi Hastanesi Acil Servise Yapılmış Şikayet Başvurularının Geriye Dönük İncelenmesi, (Yayınlanmamış Uzmanlık Tezi). İzmir.

Karataş, Z. B. (2002). Anne Baba Saldırganlığı İle Lise Öğrencilerinin Saldırganlığı Arasındaki İlişkinin Incelenmesi (Yayınlanmamış Yüksek Lisans Tezi), Çukurova Üniversitesi/Sosyal Bilimler Enstitüsü. Adana.

Keser, Ö. N. \& Bilgin, H. (2011). Türkiye'de Sağllk Çalışanlarına Yönelik Şiddet. Türkiye Klinikleri J Med Sci 2011;31(6). 1442-56. doi:10.5336/medsci.2010-20795

Köknel, Ö. (2000). Bireysel ve Toplumsal Şiddet. İstanbul: Altın Kitaplar.

Köknel, Ö. (2001). Kimliğini Arayan Gençliğimiz. İstanbul: Altın Kitaplar.

Köknel, Ö. (2005). Kaygıdan Mutluluğa Kişilik. İstanbul: Altın Kitaplar.

Kurtz, S., Silverman, J. \& Draper, J. (1998). Tipta İletişim Teknikleri. Selim Yeniçeri, Ayşegül Yurdaçalış, Murat Yaşarlar (Çev.), İstanbul: Beyaz.

Lyles, I. R. \& Joiner, C. (1986). Supervision in Health Care Organizations. New York: John Wiley \& Sons Inc.

Okay, A. (2009). Sağllk İletişimi. İstanbul: Farmaskop/ Media Cat.

Ögülmüş, S. (2001). Kişilerarası Sorun Çözme Becerileri ve Eğitimi. Ankara: Nobel Dağıtım.

Örs, Y. (1975). Geçmişte ve Günümüzde Hekim-Hasta İlişkisi. Tip Dünyası. 48(6). 224-30.

Riches, D. (1989). Antropolojik Açıdan Şiddet. Dilek Hattatoğlu (Çev.), İstanbul: Ayrıntı. 
Sadullah, Ö. (2009). İnsan Kaynakları Yönetiminde Koruma İslevi (İş Güvenliği ve İş Gören Sağllği). İnsan Kaynakları Yönetimi. İstanbul: Beta Basım Yayım Dağıtım.

Saines C., J. (1999). "Violence and Aggression in A\&E: Recommendations for Action", Accid Emerg Nurs; 7. 8-12.

Sanders, B. (1999). Öküzün A’sı, Elektronik Çağda Yazllı Kültürün Çöküşü ve Şiddetin Yükselişi. Şehnaz Tahir (Çev.), İstanbul: Ayrıntı.

Sarcan, E. (2013). Toplumun Sağlk Çalışanlarına Uygulanan Şiddete Bakış Açısı. (Yayımlanmamış Uzmanlık Tezi), Gaziantep Tip Fakültesi, Gaziantep.
Uludağ, A. (2011). Hastane Hasta Hakları Kurullarının İletişim Sorunu İçerikli Başvurulara Bakışı, Konya Hastaneleri Örneği”, Türkiye Klinikleri J MedSci;31(3):653-63. doi:10.5336/medsci.2009-16481

http://www.izmirtabip.org.tr/L/TR/mid/396/ hcid/17/hid/493/VATANDAS_ALDI\%C4\%9EI_ SA\%C4\%9ELIK_HIZMETINE_GECER_NOT_ VERMEDI!.htm.

http://www.tdk.gov.tr/index.php?option $=$ com $_{-}$ b t s \& a r a m a = ke li me \& g u id $=$ T D K. GTS.547d851ba6cb76.25455770. 